\title{
ANALISA KADAR PROTEIN CRUDE ENZIM SELULASE DARI KAPANG Rhizopuz Sp PADA SUBSTRAT AMPAS TEBU HASIL ISOLASI DARI KEBUN CENGKEH, KARE, MADIUN
}

\author{
Pujiati $^{{ }^{*}}$, Ani Sulistyarsi ${ }^{1}$, Muh. Waskito Ardhi ${ }^{1}$ \\ ${ }^{1}$ Prodi Pendidikan Biologi, Fakultas PMIPA, IKIP PGRI Madiun Madiun, 63118, Indonesia \\ *email: poesky86@gmail.com
}

\begin{abstract}
ABSTRAK
Kapang Rhizopus sp merupakan salah satu mikroorganisme yang memiliki kemampuan tinggi untuk menghasilkan enzim selulase.Enzim selulase merupakan enzim yang dapat menghidrolisis selulosa. Hidrolisis meliputi proses pemecahan polisakarida di dalam biomassa lignoselulosa, yaitu: selulosa dan hemiselulosa menjadi monomer gula penyususnnya. Penelitian ini bertujuan untuk mengetahui produksi dan aktivitas enzim selulase terhadap aktivitas crude enzim selulase dari kapang Rhizopus sp dengan subsrtat ampas tebu (bagase). Metode penelitian menggunakan kuantitatif eksperimen dengan pola rancangan acak lengkap (RAL) dua faktorial. Perlakuan penelitian meliputi perbedan inokulum $(\mathrm{K})$ yaitu $5 \%\left(\mathrm{~K}_{1}\right), 15 \%\left(\mathrm{~K}_{2}\right), 25 \%\left(\mathrm{~K}_{3}\right)$ dan lama fermentasi $(\mathrm{T})$ yaitu 3hari $\left(\mathrm{T}_{1}\right)$, 6hari $\left(\mathrm{T}_{2}\right)$, 9hari $\left(\mathrm{T}_{3}\right)$, dan 12 hari $\left(\mathrm{T}_{4}\right)$. Data yang diambil dari perlakuan tersebut adalah kadar protein dengan metode brownstead lowry. Analisis data menggunakan variansi anava dua jalur dengan taraf signifikansi 5\% setelah itu dilanjutkan dengan uji Beda Nyata Terkecil (BNT ). Hasil penelitian menunjukkan bahwa: $\mathrm{F}_{\text {hit }}>\mathrm{F}_{\text {tab }}$ sehingga ada pengaruh antara konsentrasi inokulum dan lama fermentasi terhadap aktivitas crude enzim selulase dari kapang Rhizopus sp, Perlakuan perbedaan konsentrasi dan lama fermentasi mendapatkan kadar protein tertinggi 0,715 dengan konsentrasi $25 \%$ dan lama fementasi $25 \%$.
\end{abstract}

Kata Kunci: Rhizopus sp; Ampas Tebu; Aktivitas; Selulase.

\section{PENDAHULUAN}

Tanah hutan yang dipenuhi guguran daun dan ranting-ranting membuat tanahnya subur. Tanah yang subur akibat dekomposisi dan penguraian daun beserta ranting-ranting oleh mikroorganisme menjadi unsur hara yang diperlukan oleh tumbuhan. Tanah yang subur diindikasikan populasi mikroorganisme melimpah karena banyaknya sumber energi dari reduksi senyawa-senyawa organik yang dibutuhkan oleh mikroorganisme tersebut.

Di kebun cengkeh ditemukan kapang dari beberapa genus diantaramya kapang Penicillium, kapang Aspergillus, kapang Trichoderma, dan kapang Rizhopus. Spesies kapang dari genus Rizhopus yang belum diekplorasi potensinya dari kebun cengkeh Kare kabupaten Madiun adalahRizhopus sp, sehingga perlu diadakan penelitian untuk mengetahui potensi Rizhopus sp dari tanah kebun cengkeh yang belum diketahui oleh masyarakat khususnya mahasiswa.

Produksi enzim selulase dalam skala industri membutuhkan biaya produksi tinggi sehingga enzim yang dihasilkan mahal, untuk mengatasi masalah dalam produksi enzim digunakan substrat dari limbah pertanian. Menurut Puspita, 2013: 22 dalam Sesotyaningrum, 2014:2) menyatakan produksi enzim memerlukan substrat yang biasanya berasal dari bahan berpati maupun berselulosa. Ampas tebu atau lazimnya disebut bagas, adalah hasil samping dari proses ekstraksi (pemerahan) cairan tebu.

Pada umumnya, pabrik gula di Indonesia memanfaatkan ampas tebu sebagai bahan bakar bagi pabrik yang bersangkutan setelah ampas tebu tersebut mengalami pengeringan. Disamping untuk bahan bakar, ampas tebu juga banyak digunakan sebagai bahan baku pada industri kertas. Dari limbah pertanian tersebut dapat dijadikan substrat dalam pembuatan enzim selulase karena mengandung selulosa.

Enzim selulase merupakan enzim yang digunakan untuk menghidrolisis selulosa yang banyak dimanfaatkan dalam berbagai industri. enzim selulase umumnya digunakan dalam berbagai industri seperti bioteknologi makanan, tekstil, pakan ternak, kertas, dan pertanian (Sinatari, Aminin, Sarjono 2013:131). Banyaknya kebutuhan akan enzim selulase dalam berbagai bidang industry meningkatkan minat para peneliti untuk mencari 
formula terbaik dalam menghasilkan enzim selulase ini.

Ampas tebu merupakan bahan berbasis lignoselulosa memiliki substrat yang cukup kompleks karena didalamnya terkadung lignin, polisakarida, zat ekstraktif, dan senyawa organik lainnya. Dari seluruh perkebunan tebu yang ada di Indonesia, $50 \%$ di antaranya adalah perkebunan rakyat, $30 \%$ perkebunan swasta, dan hanya $20 \%$ perkebunan negara. Pada tahun 2004 produksi gula Indonesia mencapai 2.051.000 ton (Badan Penelitian dan Pengembangan Pertanian, 2007 dalam Ganjar, 2011:180).Ampas tebu, atau disebut juga dengan bagas, adalah hasil samping dari proses ekstraksi cairan tebu. Ampas tebu sebagian besar mengandung ligno-cellulosa. Serat bagas tidak dapat larut dalam air dan sebagian besar terdiri dari selulosa, pentosan, dan lignin.

Formulasi enzim yang optimal dapat dipengaruhi oleh beberapa faktor Antara lain: konsentrasi inokulum, lama inkubasi, jenis substrat, nutrisi, $\mathrm{pH}$, kelembaban.

Penelitian ini menggunakan variasi konsentrasi inoculum Rizhopus $s p$ dan lama inkubasi untuk mendapatkan produk enzim dengan aktivitas optimal yang di peroleh dengan menganalisa kadar protein dari crude enzim yang diperoleh.

\section{METODE PENELITIAN \\ Alat dan Bahan}

Erlenmeyer, sentrifuge, pipet tetes, kertas saring, alumunium foil, tip, spatula kaca, ose, bunsen, pipet volume, autoclave, tabung reaksi, shaker, kertas label, gelas ukur, pipet micro, kapas, cawan petri, wrapping platsic, botol kaca, timbangan digital, kompor listrik,beakerphyrex, tisue, spektrofotometer.

Bahan yang digunakan dalam penelitian ini meliputi:PDA (Potato Dextrose Agar); akuades; alkohol 70\%; NaOH 6\%; amonium sulfat ((NH4)2SO4) $10 \mathrm{~g} / \mathrm{L}$; urea $(\mathrm{CO}(\mathrm{NH} 2) 2) 3 \mathrm{~g} / \mathrm{L}$; kalium dihidrogen fosfat (KH2PO4) $3 \mathrm{~g} / \mathrm{L}$; magnesium sulfat heptahidrat $(\mathrm{MgSO} 4.7 \mathrm{H} 2 \mathrm{O}) 0,5$ $\mathrm{g} / \mathrm{L}$; kalsium klorida monohidrat $(\mathrm{Kcl}) 0,5 \mathrm{~g} / \mathrm{L}$; substrat ampas tebu; Rhizopus sp hasil isolasi dari kebun cengkeh, Kare, Madiun.

\section{Prosedur Penelitian}

a. Pembuatan larutan nutrisi

Melarutkan urea $(3 \mathrm{~g} / \mathrm{L}),\left(\mathrm{NH}_{4}\right)_{2} \mathrm{SO}_{4}(10 \mathrm{~g} / \mathrm{L})$, $\mathrm{KH}_{2} \mathrm{PO}_{4} \quad(3 \mathrm{~g} / \mathrm{L}), \quad \mathrm{MgSO}_{4} .7 \mathrm{H}_{2} \mathrm{O} \quad(0,5 \mathrm{~g} / \mathrm{L})$, $\mathrm{CaCl} . \mathrm{H}_{2} \mathrm{O} \quad(0,5 \mathrm{~g} / \mathrm{L})$ dengan akuades dalam erlenmeyer.

b. Pembuatan Kultur Rhizopus sp
Kapang Rhizopus sp yang sudah tumbuh di tabung reaksi menggunakan pipet mikro kemudian dimasukkan kedalam botol berisikan air fisiologis $300 \mathrm{ml}$ yang sudah disterilkan.Botol ditutup menggunakan kapas dan aluminium foil dan disimpan selama 3 hari dengan suhu $30^{\circ} \mathrm{C}$.

c. Produksi enzim selulase

Tahap produksi enzim yakni dengan memasukkan larutan nutrisi dan penambahan substrat Bagase (Ampas tebu). Starter kapang Rhizopus sp diinokulasikan pada media tersebut dengan konsentrasi $5 \%\left(\mathrm{~K}_{1}\right), 15 \%\left(\mathrm{~K}_{2}\right), 25 \%$ (K3) dan diinkubasi dengan lama inkubasi 3, 6, 9 dan 12 hari.

d. Ekstraksi enzim

Ekstraksi enzim dilakukan dengan cara menambahkan larutan pengekstrak kultur yang telah diinkubasi Kemudian disentrifuge untuk menghasilkan filtrat enzim kasar. Ekstrak enzim kasar ini digunakan untuk analisa kadar protein.

e. Penentuan kadar protein

Penentuan total protein sampel:

Albumin pada cuplikan sampel $(\mathrm{x})=\frac{\text { absorbansi-0,0116 }}{0,0052}$ Albumin pada sampel $(\mathrm{g} / 100 \quad \mathrm{ml})=$ $\frac{\mathrm{x}}{\text { bobot sampel } \times 1000 / 10} \times \mathrm{fp} \times 100 \%$

Keterangan:

$\mathrm{fp}$ : faktor pengenceran, $\mathrm{fp}=1$ (tanpa pengenceran)

Analisis data untuk mengetahui produksi dan uji aktivitas enzim selulase dari kapang Rhizopus sp dari substrat Bagase (ampas tebu) yaitu dihitung dengan mengunakan SPSS versi 16.0. Untuk mengetahui signifikan atau tidak nya produksi dan uji aktivitas enzim selulase kapang Rhizopuz $s p$ pada substrat ampas tebu digunakan statistik anava dua jalur dilanjutkan dengan uji LSD.

\section{HASIL DAN PEMBAHASAN}

Hasil analisis penelitian menunjukkan bahwa dengan perlakuan lama kosentrasi inokulum dan lama terhadap kadar gula reduksi dan kadar protein dari aktifitas crude enzim kapang Rhizopus sp memiliki perbedaan yang signifikan sebesar $0,00<$ 0,05 dengan taraf signifikan 95\%. Berdasarkan Tabel 4.1 data hasil pengujian kadar gula reduksi kapang Rhizopus sp menunjukkan bahwa konsentrasi inokulum dan lama fermentasi mempengaruhi produktivitas crude enzim selulase yang dihasilkan oleh kapang Rhizopus sp yang diukur dengan prosentase kadar protein. Berikut disajikan grafik pengaruh lama fermnatsi dan 
konsentrasi kapang Rhizopus sp pada substrat gambar 1.

ampas tebu terhadap kadar protein dapat dilhat pada

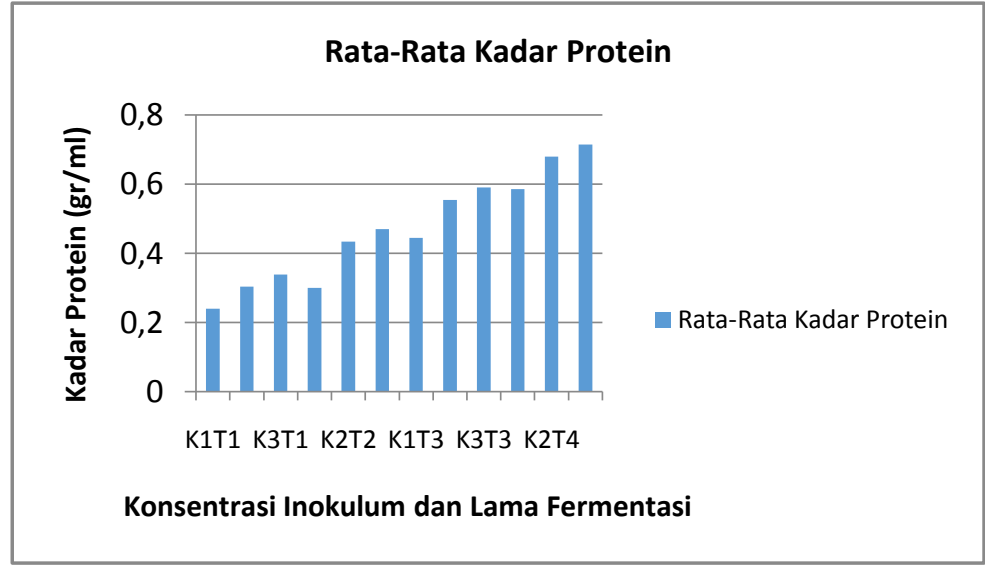

Gambar 1.Histogram rata-rata kadar protein reduksi kapang Rhizopus sp pada crude enzim selulase

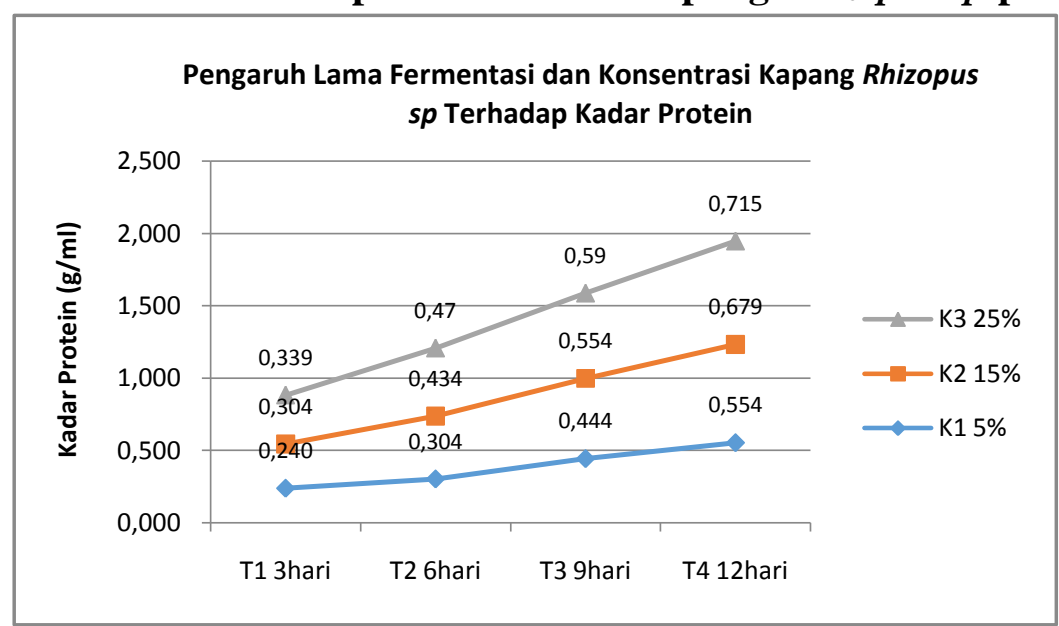

Gambar 2. pengaruh lama fermentasi dan konsentrasi kapang Rhizopus sp pada substrat ampas tebu terhadap kadar protein

Tabel 1. Tabel Uji LSD Kadar Gula Reduksi Crude Enzim Selulase Kapang Rhizopus sp Terhadap Pengaruh Lama Fermentasi

\begin{tabular}{|c|c|c|c|c|c|}
\hline \multicolumn{6}{|c|}{$\begin{array}{c}\text { Dependent Variable: Protein total } \\
\text { LSD }\end{array}$} \\
\hline $\begin{array}{c}\text { (I) } \\
\text { Lama } \\
\text { Fermentasi }\end{array}$ & $\begin{array}{c}(\mathrm{J}) \\
\text { Lama } \\
\text { Fermentasi }\end{array}$ & $\begin{array}{c}\text { Mean } \\
\text { Difference (I-J) }\end{array}$ & Std. Error & Sig. & $\begin{array}{l}\text { 95\% Confidence } \\
\text { Interval } \\
\text { Lower Bound }\end{array}$ \\
\hline \multirow{3}{*}{$\mathrm{T} 1$} & T2 &,$- 1067^{*}$ & ,00439 & ,000 &,- 1162 \\
\hline & T3 &,$- 2350^{*}$ & 00439, & 000 &,- 2446 \\
\hline & $\mathrm{T} 4$ &,$- 3650^{*}$ & ,00439 &, 000 &,- 3746 \\
\hline \multirow{3}{*}{$\mathrm{T} 2$} & $\mathrm{~T} 1$ &, $1067^{*}$ & ,00439 &, 000 & 0971 \\
\hline & $\mathrm{T} 3$ &,$- 1283^{*}$ & ,00439 & ,000 &,- 1379 \\
\hline & $\mathrm{T} 4$ &,$- 2583^{*}$ & ,00439 & ,000 &,- 2679 \\
\hline \multirow{3}{*}{$\mathrm{T} 3$} & $\mathrm{~T} 1$ & $2350^{*}$ & ,00439 & ,000 & ,2254 \\
\hline & $\mathrm{T} 2$ & ,1283" & ,00439 &, 000 & 1188 \\
\hline & $\mathrm{T} 4$ &,$- 1300^{*}$ & ,00439 & ,000 &,- 1396 \\
\hline \multirow{3}{*}{$\mathrm{T} 4$} & $\mathrm{~T} 1$ &, $3650^{*}$ & ,00439 & ,000 & ,3554 \\
\hline & $\mathrm{T} 2$ &, $2583^{*}$ & ,00439 & ,000 & 2488 \\
\hline & $\mathrm{T} 3$ & $1300^{*}$ & ,00439 &, 000 & , 1204 \\
\hline
\end{tabular}

Tabel 2. Tabel Uji LSD Kadar Gula Reduksi Crude Enzim Selulase Kapang Rhizopus sp Terhadap Pengaruh Lama Fermentasi 


\begin{tabular}{ccc} 
& & Upper Bound \\
\hline \multirow{2}{*}{ T1 } & T2 &,$- 0971^{*}$ \\
& T3 &,$- 2254^{*}$ \\
& T4 &,$- 3554^{*}$ \\
T2 & T1 &, $1162^{*}$ \\
& T3 &,$- 1188^{*}$ \\
& T4 &,$- 2488^{*}$ \\
& T1 &, $2446^{*}$ \\
T3 & T2 &, $1379^{*}$ \\
& T4 &,$- 1204^{*}$ \\
& T1 &, $3746^{*}$ \\
& T2 &, $2679^{*}$ \\
T4 & T3 &, $1396^{*}$ \\
\hline
\end{tabular}

Based on observed means.

The error term is Mean Square(Error) $=5,775 \mathrm{E}-005$.

*. The mean difference is significant at the ,05 level.

Berdasarkan gambar 1 dan 2 dapat dilihat bahwa rata-rata kadar protein tertinggi pada $\mathrm{K}_{3} \mathrm{~T}_{4}$ (konsentrasi inokulum 25\% dan lama fermentasi 12 hari) dengan rata-rata kadar protein $0,715 \mathrm{gr} / \mathrm{ml}$ dan kadar terendah pada $\mathrm{K}_{1} \mathrm{~T}_{1}$ (konsentrasi $5 \%$ dan lama fermentasi 3 hari) dengan rata-rata kadar protein yaitu sebesar $0,24 \mathrm{gr} / \mathrm{ml}$.

Bila dikaitkan dengan tabel sidik ragam konsentrasi inokulum mempengaruhi kadar protein yang dihasilkan kapang selulolitik dengan menggunakan substrat ampas tebu, dengan kadar tertinggi pada $\mathrm{K}_{3}$ ( Konsentrasi 25\%). Menurut Septiningrum (dalam Suciningtias,2014: 39) jika jumlah inokulum lebih besar dari $10 \%$ maka akan terjadi kompetisi jamur untuk mendapatkan nutrisi didalam proses fermentasi akibatnya biomassa yang terbentuk tidak maksimum sehingga produksi selulase menjadi berkurang. Pada konsentrasi $15 \%$ mengalami penurunan, hal ini disebabkan masa optimum kapang Rhizopus sp telah mencapai nilai maksimal dan juga dipengaruhi oleh substrat yang digunakan tidak mengalami pengayakan dengan baik sehingga mikroorganisme tersebut sulit untuk melakukan hidrolisis. Kadar protein tertinggi pada $\mathrm{T}_{4}$ (lama fermentasi 12 hari). Hasil penelitian ini sejalan dengan pernyataan Zulfatus Sa'adah (dalam Suciningtias,2014: 38) yang menyatakan dengan bertambahnya waktu konsentrasi protein menjadi tinggi, hal ini disebabkan pada waktu tersebut pertumbuhan mikroba telah mencapai maksimal. Meningkatnya kadar protein menunjukkan bahwa aktivitas selulase juga meningkat. Semakin lama waktu fermentasi maka kadar protein terlarut yang dihasilkan cenderung meningkat.

Kadar protein tertinggi yaitu $\mathrm{K}_{3} \mathrm{~T}_{4}$ ( konsentrasi $25 \%$ dan lama fermentasi 12 hari). Kadar protein kapang Rhizopus sp yang cukup tinggi pada hari ke 12 dengan rata-rata 0,715 .
Hasil penelitian ini sejalan dengan hasil penelitian Ida Bagus Wayan (dalam Suciningtias, 2014: 39) yang menyatakan pada kondisi lingkungan dengan kadar protein yang dihasilkan tinggi maka aktivitas enzim juga tinggi, dan sebaliknya pada kondisi bila kadar protein yang dihasilkan rendah maka terlihat adanya aktivitas enzim yang dihasilkan rendah.

\section{KESIMPULAN}

Berdasarkan penelitian yang telah dilakukan dapat disimpulkan bahwa. Ada pengaruh perbedaan konsentrasi inokulum dan lama inkubasi terhadap kadar protein crude enzim selulase dari kapang Rhizopus sp. pada $\mathrm{K}_{3} \mathrm{~T}_{4}$ (konsentrasi inokulum $25 \%$ dan lama fermentasi 12 hari) dengan rata-rata kadar protein $0,715 \mathrm{gr} / \mathrm{ml}$ dan kadar terendah pada $\mathrm{K}_{1} \mathrm{~T}_{1}$ (konsentrasi 5\% dan lama fermentasi 3 hari) dengan rata-rata kadar protein yaitu sebesar $0,240 \mathrm{gr} / \mathrm{ml}$.

\section{DAFTAR PUSTAKA}

[1] Allita Yosephine, Victor Gala., Aning A., Ery Susiany R. Pemanfaatan Ampas Tebu dan Kulit Pisang Dalam Pembuatan Kertas Serat Campuran. (Online), (http://jurnal Teknik Kimia Indonesia, vol.2, No 2, 2012, 94-100). Diakses 2 juli 2016 jam 09:30.

[2] Dwidjoseputro,D. 2003. Dasar-Dasar Mikrobiologi. Jakarta: Penerbit Djambatan.

[3] Ganjar Andika, 2011. Hidrolisis Ampas Tebu Menjadi Furfural Dengan Katalis Asam Sulfat. (Online), (http://Jurnal Teknologi Volume 4 nomor 2, Desember 2011, 180-80).

[4] Ida, Bagus W., Wayan, Redi., Dan Ida, Bagus N. 2011. Produksi Selulase Kasar Dari Kapang Trichoderma Viride Dengan Perlakuan Konsentrasi Subsrat Ampas Tebu Dan Lama Fermentasi. Jurnal Biologi No.2 Hal: 29-33. Diunduh tanggal 23 maret 2016. 
[5] Mutiara, 2012. Potensi kapang aspergillus sp. Dalam proses hidrolisis untuk produksi etanol dari Sampah sayur dan buah pasar wonokromo Surabaya. Diakses tanggal 26 juli 2014.

[6] Selviza, Safaria., Nora, Idiawati., Dan Titin, Anita Zaharah. 2013. Efektivitas Campuran Enzim Selulase Dari Aspergilus Niger Dan Trichoderma Reesei Dalam Menghidrolisis Substrat Sabut Kelapa. Volume 2 No. 1 Hal: 46-51. Diakses tanggal 20 juni jam 21:25.

[7] Sinatari, dkk. 2013. Pemurnian Selulase Dari Isolasi Kb Kompos Termofilik Desa Bayat KLaten Menggunakan Amonium Sulfat. Chen Info (Online), Vol 1 No.1, (http://portalgaruda.org, Diunduh tanggal 29 maret 2016).

[8] Subandi. 2010. Mikrobiologi Perkembangan, Kajian, Dan Pengamatan Dalam Perspektif Islam. Bandung: PT Remaja Rosdakarya.

[9] Suciningtiyas D. D, 2014. Pengaruh Perbedaan Konsentrasi Inokulum Dan Waktu Inkubasi Terhadap Produktivitas Crude Enzim Selase Kapang Trichoderma Sp Dengan Substrat Jerami Padi (Oryza Sativa) Sebagai Bahan Penyusun Petunjuk Praktikum Mikrobiologi Bab Isolasi Kapang. Skripsi tidak diterbitkan. Madiun: PROGRAM STUDI PENDIDIKAN BIOLOGI IKIP PGRI MADIUN.

[10] Sugiyono. 2014. Metode Penelitian Kombinasi (Mixed Methoods). Bandung: Alfabeta.

[11] Sukma,2014. Optimasi Waktu Inkubasi Produksi Enzim Selulase Oleh Aspergillus Niger Menggunakan Fermentasi Substrat Padat. BIOPROPAL INDUSTRI Vol. 5 No.2, Desember 2014.
[12] Sesotyaningrum D.W, 2014. Pengaruh Perbedaan Konsentrasi Inokulum dan Waktu Inkubasi Terhadap Produktivitas Crude Enzim Selase Kapang Trichoderma Sp Dengan Substrat Jerami Padi (Oryza Sativa) Sebagai Bahan Penyusun Petunjuk Praktikum Mikrobiologi Bab Isolasi Kapang. Skripsi tidak diterbitkan. Madiun: PROGRAM STUDI PENDIDIKAN BIOLOGI IKIP PGRI MADIUN.

[13] Solikati W, 2014. Pengaruh Perbedaan Konsentrasi Inokulum Dan Lama Inkubasi Terhadap Aktivitas Crude Enzim Selulase Dari Kapang Aspergillus Niger Dengan Substrat Jerami Sebagai Bahan Petunjuk Praktikum Mikrobiologi Materi Isolasi Mikroba. Skripsi tidak diterbitkan. Madiun: PROGRAM STUDI PENDIDIKAN BIOLOGI IKIP PGRI MADIUN.

[14] Villee, Claude A., Warren F. Walker, Jr., Robert D. Barnes. 1988. Zoologi Umum. Edisi Keenam. Terjemahan oleh Nawangsari Sugiri. Jakarta : Erlangga.

[15] Waluyo. 2005. Mikrobiologi Umum. Malang: Penerbitan Universitas Muhamadiyah Malang.

[16] . 2011. Mikrobiologi Umum Edisi Revisi. Malang: UPT. Penerbitan Universitas Muhamadiyah Malang.

[17] Zulfatus Sa'adah, dkk. 2008. Produksi Enzim Selulase oleh Aspergillus niger Menggunakan Substrat Jerami dengan Sistem Fermentasi Padat. (Online), (http://eprints.undip.ac.id, Diunduh juni 2016). 